\title{
PROSPECTS FOR THE DEVELOPMENT OF EQUITY RELEASE PRODUCTS IN POLAND - REVERSE MORTGAGE FROM A CULTURAL PERSPECTIVE
}

\author{
Piotr Zbrojewski, M.Sc. \\ Department of Investment and Real Estate \\ University of Lodz \\ e-mail:zbrojpiotr@onet.eu
}

\begin{abstract}
At the time of crisis, which involves state funded benefits as well as an increase in public debt, the members of the European Union are forced to consolidate their budgetary expenses. The social cost, however, is extremely high, as the general public is unwilling to accept it. Demographic experts predict a decrease in the amount of people at an economically productive age, not to mention the continuously growing life expectancy. This fact will have serious economic consequences in Poland. That is why the pension system reform was initiated. The inevitable cuts in spending on welfare benefits might cause a situation in which one of the possibilities of increasing retirement benefits leads to the use of the most valuable and long-lasting assets that can be found in households - real estate. A financial instrument called reverse mortgage enables the gradual liberalization of the value of real estate and, thereby, can be used as an additional source of retirement income.

In Poland, the lack of verification by the Polish Financial Supervision Authority and legislative regulations as far as contractors and consumers are concerned, may pose a potential risk. There are two main problems, namely, the legal status of companies that offer reverse mortgages (in the case of possible bankruptcy and debt vindication) as well as issues concerning cyclic value changes on real estate markets. Because of the lack of a reverse mortgage bill, there is no institution which can control the financial situation of contractors, thereby guaranteeing the safety of potential customers.

The goal of this article is to determine the prospects of the development of reverse mortgage in Poland from a cultural perspective in terms of potential client preferences by carrying out a survey among people aged 18 to 30 (mostly students from different cities) and senior citizens over the age of 60. The other aim is to assess the influence of cultural determinants on the perception of equity release products. The author poses a question: In what way does ownership and inheritance attitude influence the volume of reverse mortgage sales?
\end{abstract}

Keywords: equity release, reverse mortgage, cultural factor.

JEL Classification: R 20, R 38.

Citation: Zbrojewski P., (2013), "Prospects for development of equity release products in Poland reverse mortgage from a cultural perspective", Real Estate Management and Valuation, vol. 21, no. 2, pp. 5-12.

DOI: $10.2478 /$ remav-2013-0011.

\section{Introduction}

Most entities on the financial services market adjust their offers so as to get access to as many clients as possible. Economic subjects are becoming more and more interested in senior citizens (they are gradually becoming the target group). Reverse mortgages are included in equity release financial products; they enable the transformation of illiquid capital accumulated in real estate into liquid financial means (REVERSE Mortgage Bill Project 2011, p.4). We can distinguish two models of equity 
release: the sale model, in which a property title can be transferred to a third party and which is simultaneous with the establishment of lifelong residency in a given real estate, and the credit model called a reverse mortgage, which is a kind of credit with a hedge mortgage. Repayment of the later is obtained from the sale of real estate after the demise of the borrower (REVERSE MORTGAGE BILL PROJECT 2011, p.4).

Since 2008, some specialized entities have appeared on the Polish market. They are based on the annuity agreement (civil code article 908-916) and offer life annuity in exchange for the transfer of the property title. This activity is included in the sale model in which the financial institution (the purchaser of real estate) establishes, for the sake of seller, personal easement of a house or flat. The necessity of bearing costs connected with a given piece of real estate, in particular the rent and taxes, by the economic subject who is to purchase the real estate is a feature of the sale model (MAJ WAŚNIOWSKA, CYCOŃ 2011, p. 201).

Cyclical changes of prices on the real estate market are a source of insecurity for companies which results in financial difficulties such as liquidity. According to the sale model, a contractor is responsible for the prospective disadvantageous fluctuation of prices (MAJ - WAŚNIOWSKA, CYCOŃ 2011, p.197). A legal form of the institution offering the agreement is crucial for a potential legal claim caused by the bankruptcy of a contractor. There are three main business entities in the Polish market: Fundusz Hipoteczny DOM (Mortgage Fund DOM), Fundusz Hipoteczny Familia (Mortgage Fund Familia) and Centralny Fundusz Hipoteczny (the Central Mortgage Fund). Two of them (Mortgage Fund DOM and the Central Mortgage Fund) act as limited liability companies (ltd) while the third is a joint-stock company. These firms are not supervised by the Polish Financial Supervision Authority. There is no possibility of controlling their current financial situation. There is no entity which can supervise the financial safety of people who signed an agreement with a Mortgage Fund. From the standpoint of a potential customer (retiree), it is absolutely essential to incorporate the obligation to present detailed information on the financial product in order to find a future legislative solution (Reverse Mortgage Bill Project 2011, p.14). A Polish contractor (in the sale model) does not have to account for an inheritor in a situation when the amount of money received from the sale of a given piece of real estate is higher than the benefit from the annuity agreement in the current legal status (MAJ - WAŚNIWOSKA, CYCOŃ 2011, p. 202).

On account of the many risks posed to both customers and contractors, the Ministry of Finance has begun to work on drafting a reverse mortgage bill. The credit model was presented in "The Reverse Mortgage Bill project 2011" from September 23rd 2011. One of the most important differences, in comparison to the sale model, is the transfer of property title after the end of a contractual relationship (after the death of the property holder but not in a situation when inheritors are to pay off the amount of mortgage credit). The mortgage fund will be obliged to repay the surplus (over the amount of mortgage credit) obtained from the sale of the real estate. In a situation where the financial means gained from the sale are smaller than the benefits transferred to the purchaser in a reverse mortgage scheme, the contractor will not be allowed to charge the inheritors with the resulting difference. Consumers will be responsible for keeping the real estate in a non-deteriorated condition, paying all charges and taxes. In a credit model, which is under preparation by the Ministry of Finance, the granting of reverse mortgages will be limited to institutions such as banks, departments of foreign banks and credit institutions. They will be supervised in this field by the Polish Financial Supervision Authority. The signing of a reverse mortgage agreement will be equivalent to a credit agreement, despite the fact that the borrower will not be obligated to repay it. The capital gained as a result of the agreement will not be a taxable income (ReVerse Mortgage Bill Project 2011, p. 40).

\section{Methodology, Life Cycle Theory}

The research was conducted as a questionnaire survey in Lodz, the main purpose of which was to compare the attitudes towards reverse mortgage of two age groups. A total of 304 respondents participated in the study (150 aged 18 - 30 who were mostly students from different cities and 154 senior citizens over the age of 60). The research sample was not a random sample.

According to the Life Cycle Theory (TousSAINT 2011, p. 3), the incomes of young households are normally below their average expected lifetime income. Therefore, young adults have a higher inclination to borrow in order to increase the level of consumption. The middle-aged tend to save to build up assets, as their income is normally higher than the lifetime average. This implies the possibility to amass wealth, which will provide provision in their old age. Contrarily, the elderly 
consume their assets because their incomes are very often lower than their lifetime average. The Life Cycle Theory expects an inverted $U$ - shape pattern to apply to savings across the age categories. Households are motivated to save in order to maintain static consumption levels over the course of their members' lives. Do the research findings of the presented trial confirm the main assumptions of the Life Cycle Theory?

\section{Social Perception of reverse mortgage}

The most characteristic feature of the research sample was a low share of respondents aged 18 - 30 who possess real estate (defined as residential property, land property or a single family home), and relatively high share of people over 60 years of age who own such an asset $(74.7 \%$ in comparison with $91.8 \%$ in the group aged 18 - 30 without a property title). Research conducted on the presented study group therefore confirmed the main assumptions of the Life Cycle Theory.

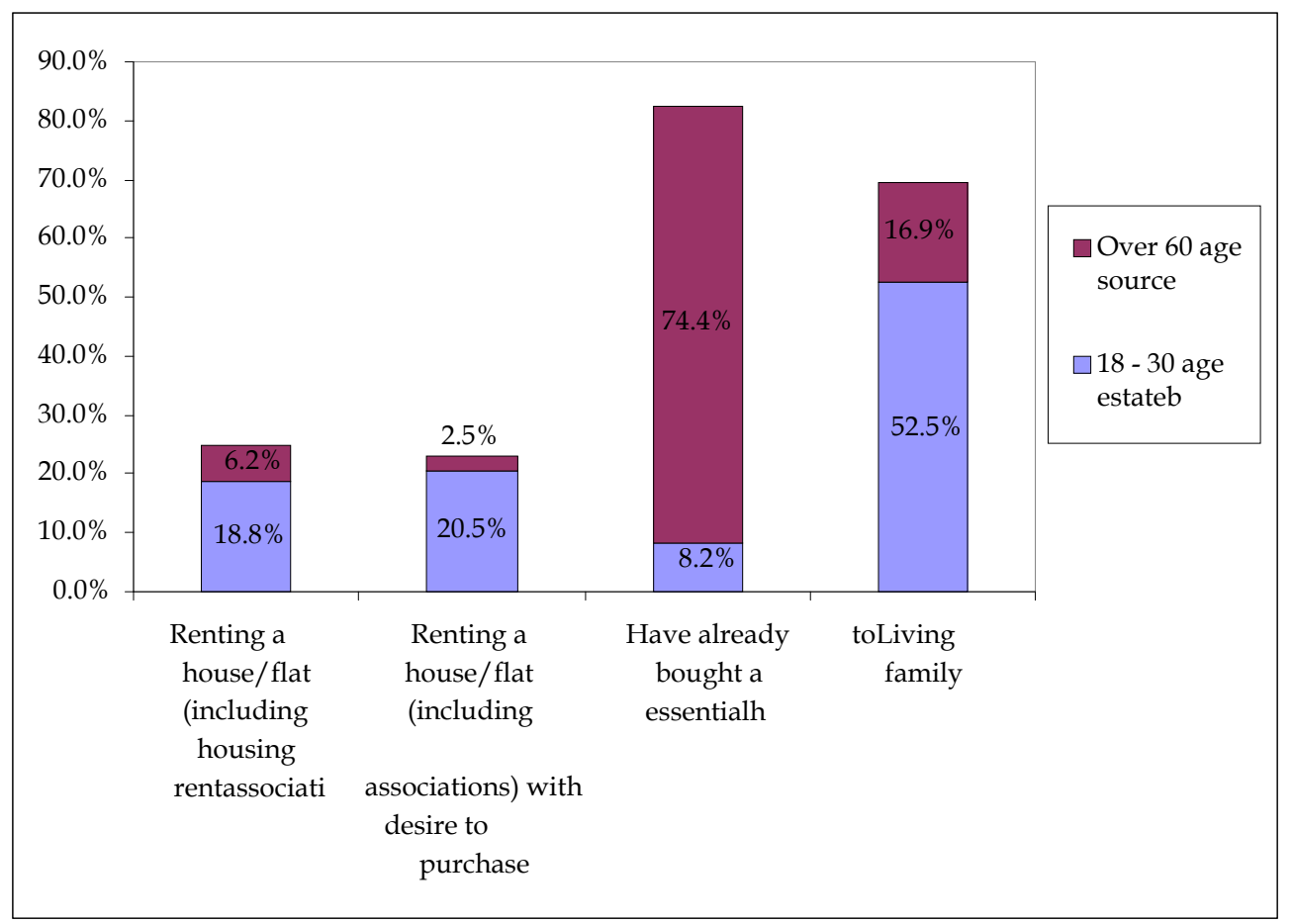

Fig. 1. Means of satisfying housing needs. Source: own elaboration based on a questionnaire survey.

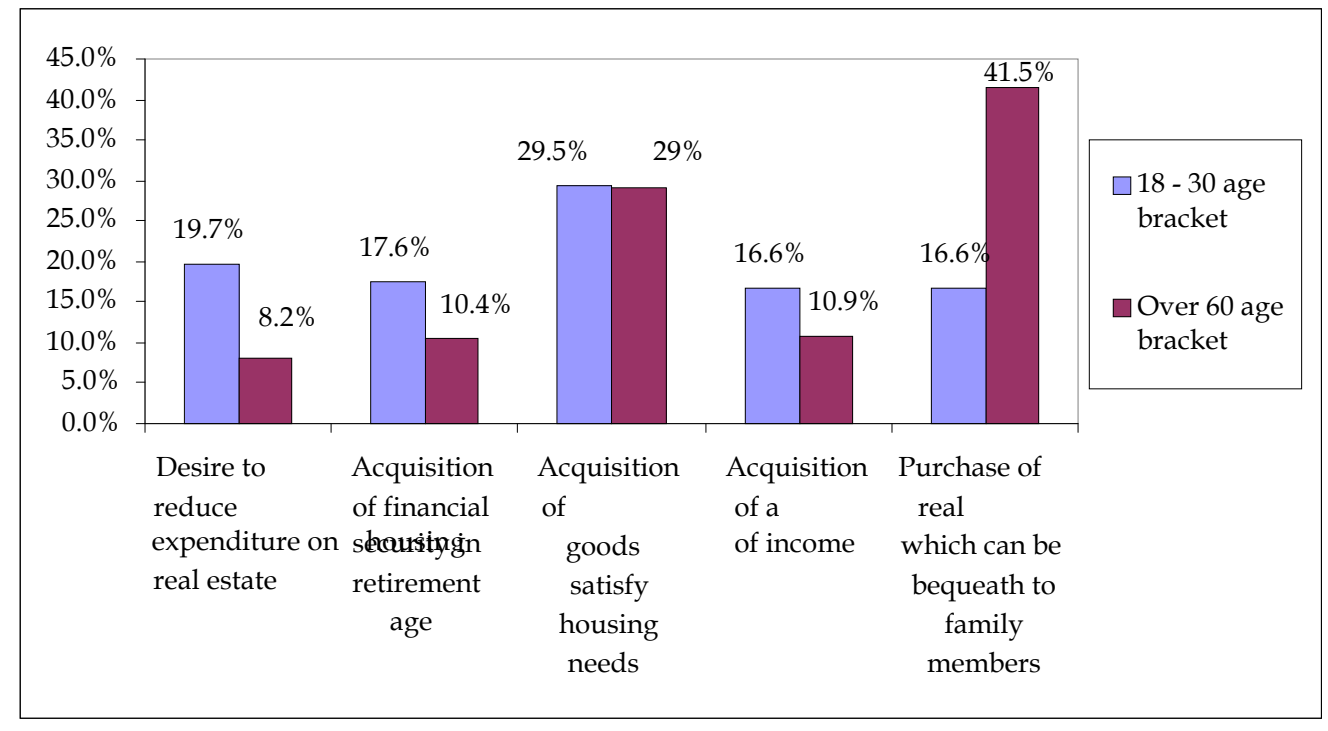

Fig. 2. Main motivation behind buying real estate. Source: own elaboration based on a questionnaire survey. 
As a result of the conclusion of the "Family on its own" program and protracted legislative work on substitute programs supporting young people intending to buy a flat, the majority of respondents aged 18-30 declared living with their parents (figure 1). Among the tenants in this age group, a slightly higher percentage declared a willingness to purchase real estate in the future, if their financial situation allowed them to do so (figure 1).

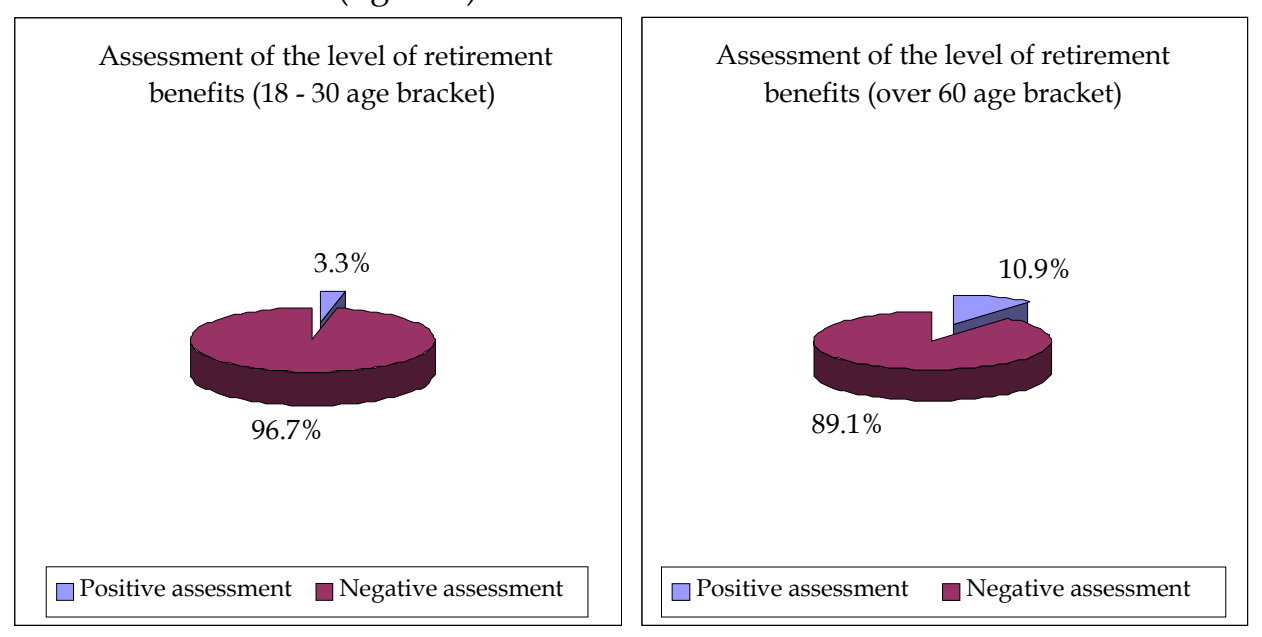

Fig. 3. Assessment of the level of retirement benefits. Source: own elaboration based on a questionnaire survey.

The reason behind this might be the fact, that property owners have an advantage over tenants after repaying their financial obligation. They have a far smaller financial burden and the possibility to have property at their disposal. Real estate is not treated as a source of potential provision by people over 60 years of age in their retirement. The predominant premise for purchasing property is to leave a legacy to members of their family (figure 2). In well-developed reverse mortgage markets, the purchase of real estate is a way to redistribute wealth to the retirement stage of the owners' lives. However, cultural factors in Poland cause the elderly to lose interest in selling as they would instead like to leave a legacy. A significant motivation for buying property by those of the discussed age groups is receiving goods, essential for addressing housing needs. The unambiguous negative assessment of the current level of pensions (by both age groups, figure 3) implies that receiving life annuity thanks to the sale model which is present in the Polish market, would result in the enlargement of disposable income, increasing the level of consumption among older people.

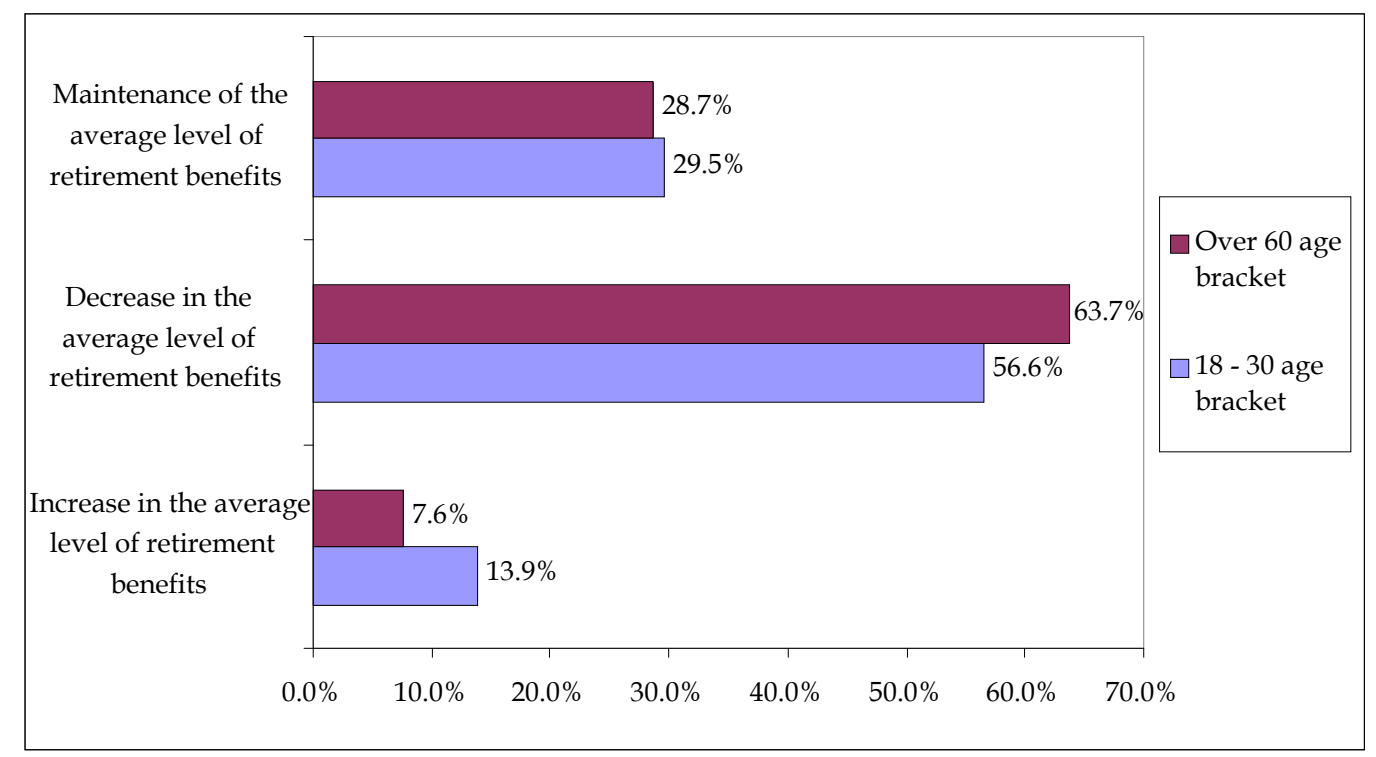

Fig. 4. Predictable changes in the level of retirement benefits resulting from the pension system reform. Source: own elaboration based on a questionnaire survey. 
There is very negative feedback concerning changes in the pension system, particularly among respondents aged $18-30,97 \%$ of who are not satisfied with the current level of pensions (figure 3). The necessity of prolonging the working age, to 65 and 67 for men and women respectively, contributes to the negative assessment of the Polish pension system. Almost $82 \%$ of Poles are opposed to raising the retirement age (Center of Public Opinion Research 2012). In the examined research sample, a pessimistic attitude towards the pension system reform prevails, as it is expected to result in a decrease in the average level of retirement benefits (figure 4).

\section{Prospects for the development of reverse mortgage in Poland}

Does the equity release market in Poland have a chance for development in the light of inevitable welfare expenditures, cuts and an anticipated decrease in the conversion rate of retirement benefits? Due to marketing campaigns directed mainly at pensioners, the awareness of the possibility to release value from the most illiquid of assets of their portfolios - real estate - is still growing. Approximately $66 \%$ of respondents over 60 recognize the concept of a reverse mortgage (unlike the group of $18-30$ years old, in which $69.4 \%$ are not familiar with it). The majority of respondents in the research sample (in both age groups) are not inclined to sign a reverse mortgage agreement (figure 5). In the age group of over 60 -year-olds, $94.3 \%$ of the respondents are not interested in receiving life annuity on the basis of the credit model (as a result of prolonged work on the reverse mortgage bill, only the sale model is available on the market, based on the annuity agreement regulated in the civil code).

People aged 18 - 30 are more inclined to sign an agreement of reverse mortgage $(16.8 \%$, figure 5$)$. This might reflect some uncertainty in terms of the level of consumption after a period of professional activity and presumably a greater need for receiving an additional source of income on top of the low pension.

It is essential to pose questions regarding the motivation driving people who are interested in receiving additional money through a reverse mortgage agreement. The major motivating factor for people who are keen on signing such an agreement is of financial nature (figure 6). The motivation to avoid a decrease in prices and difficulties connected with the selling process due to the low liquidity of real estate seem to be of little significance. The main reason behind the reluctance towards signing a reverse mortgage in both age groups is the desire to leave a legacy to family and children (figure 7). As a result of the cultural factor, the strengthening of family ties (not necessarily formalized) and material solidarity among their members are the main premises not to sell real estate and not to sign a reverse mortgage agreement in its present form.

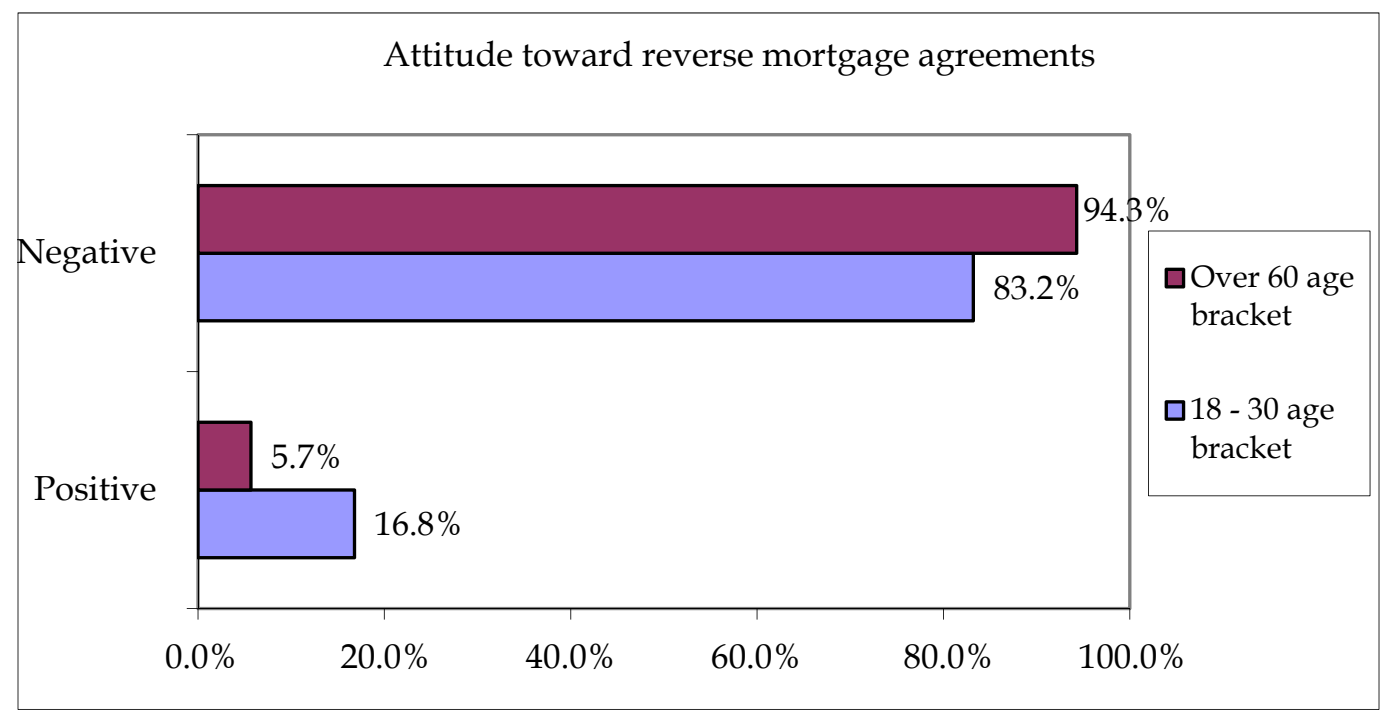

Fig. 5. Attitude towards reverse mortgage agreements. Source: own elaboration based on a questionnaire survey.

The study results show that as many as $64.2 \%$ of the respondents stated that children should help their parents financially when they reach retirement age. Interestingly, in the age group of people over 60 , those preferences might be described as reversed and symmetrical (58.2\% of respondents declared that parents should support their children financially). 
Ownership plays a more crucial role in countries where welfare provisions and the affluence of society are decreasing (Toussaint, Elsinga 2007, p. 166). There is a very strong attachment to ownership in Poland. The attitude towards inheritance serves as proof of this. The preferences of both age groups concerning the possibility of leaving a legacy to the family are comparable (figure 8). Approximately $90 \%$ of the respondents expressed a desire to do so.

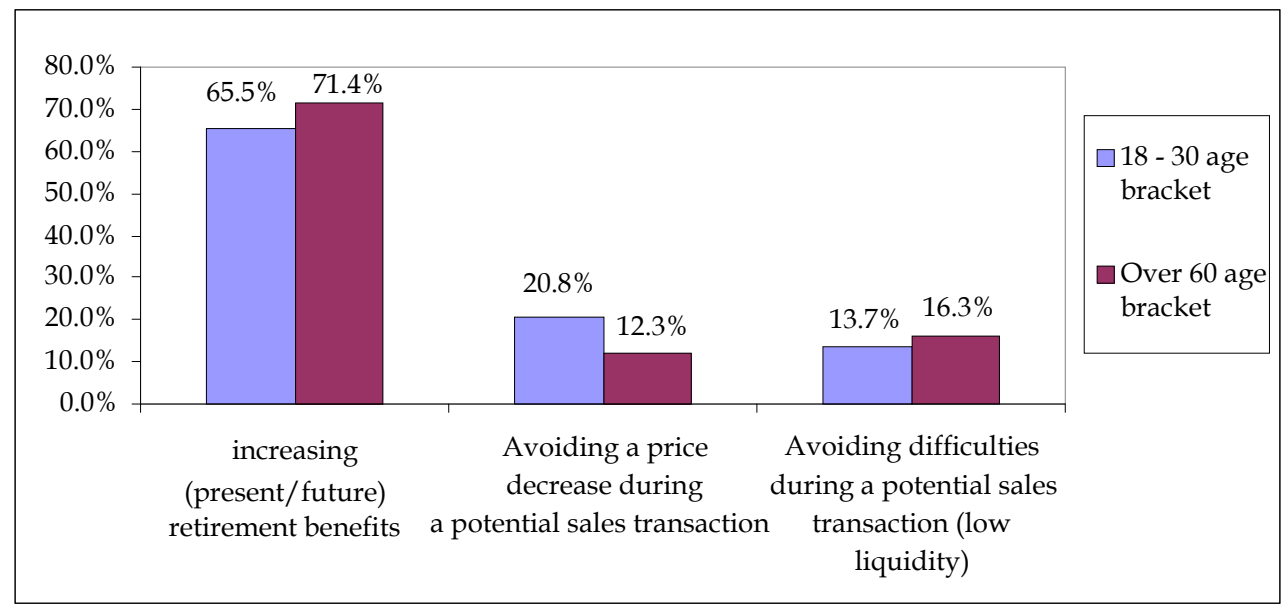

Fig. 6. Main motivations for signing a reverse mortgage agreement. Source: own elaboration based on a questionnaire survey.

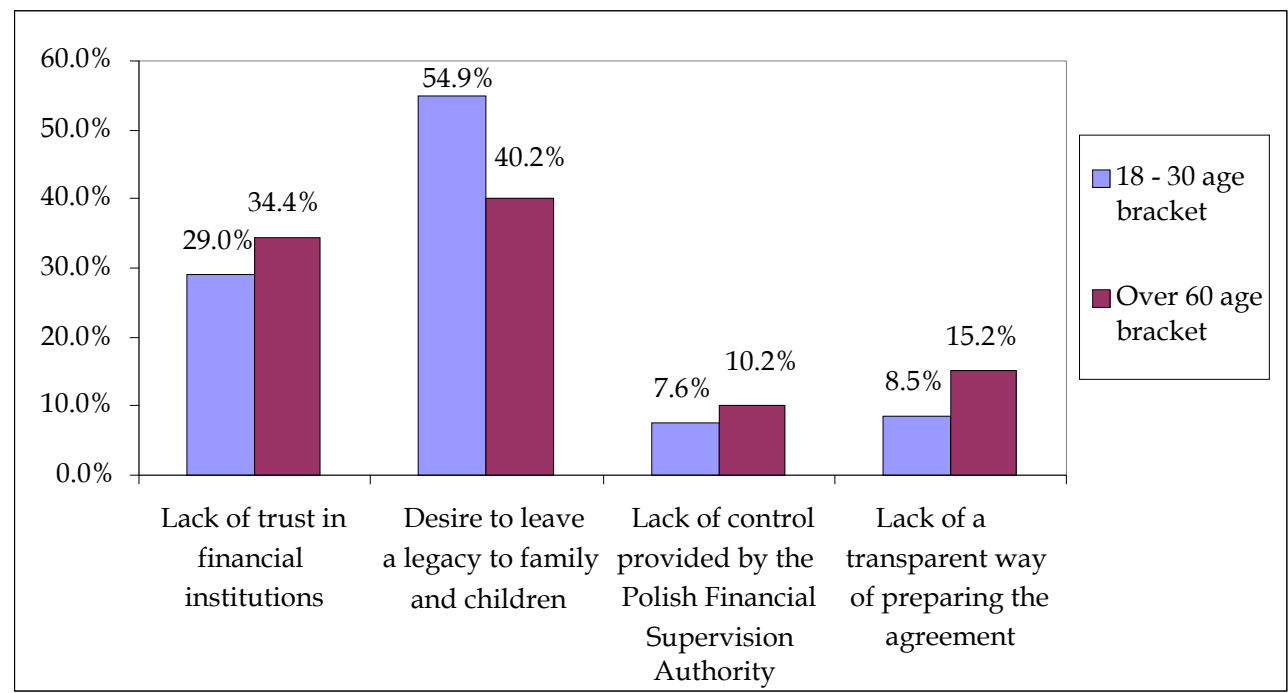

Fig. 7. Main reasons behind the reluctance to sign a reverse mortgage agreement. Source: own elaboration based on a questionnaire survey.

These attitudes do not seem to be connected with the present family situations. In the case of both groups of respondents, those aged $18-30$ (99.2\% of whom were childless students) as well as those over 60 (78.2\% of whom had children), the majority expressed intergenerational solidarity and a desire to leave their wealth to future inheritors. This indicates the strengthening of the ownership pattern, handed over by family members. Does financial status have an influence on people's attitudes towards taking out a reverse mortgage? No less than $87.5 \%$ of respondents aged $18-30$ spend PLN 1,500 per month (figure 9). There is greater dispersion of monthly expenditure in the age group of over 60 year-olds. Admittedly $50.3 \%$ of them spend less than PLN 1,500, but another $39.4 \%$ declared a monthly expenditure of up to PLN 2,500 per month (figure 9).

Only $5.7 \%$ of the elderly respondents declared an inclination towards signing a reverse mortgage agreement (figure 5). Almost three times as many people aged 18-30 were willing to sign this type of agreement $(16.8 \%$, figure 5$)$, most likely due to their worse financial situation (figure 9). The reason behind that might be the fact that pensioners adjust their consumption level to their retirement pension and do not sell their property. If financial problems arise, they tend to first liquidate their 
reserves such as: savings, valuables, or financial products such as shares in investment funds, leaving real estate at the end of the list of assets. This makes it possible for them to maintain their former level of consumption.

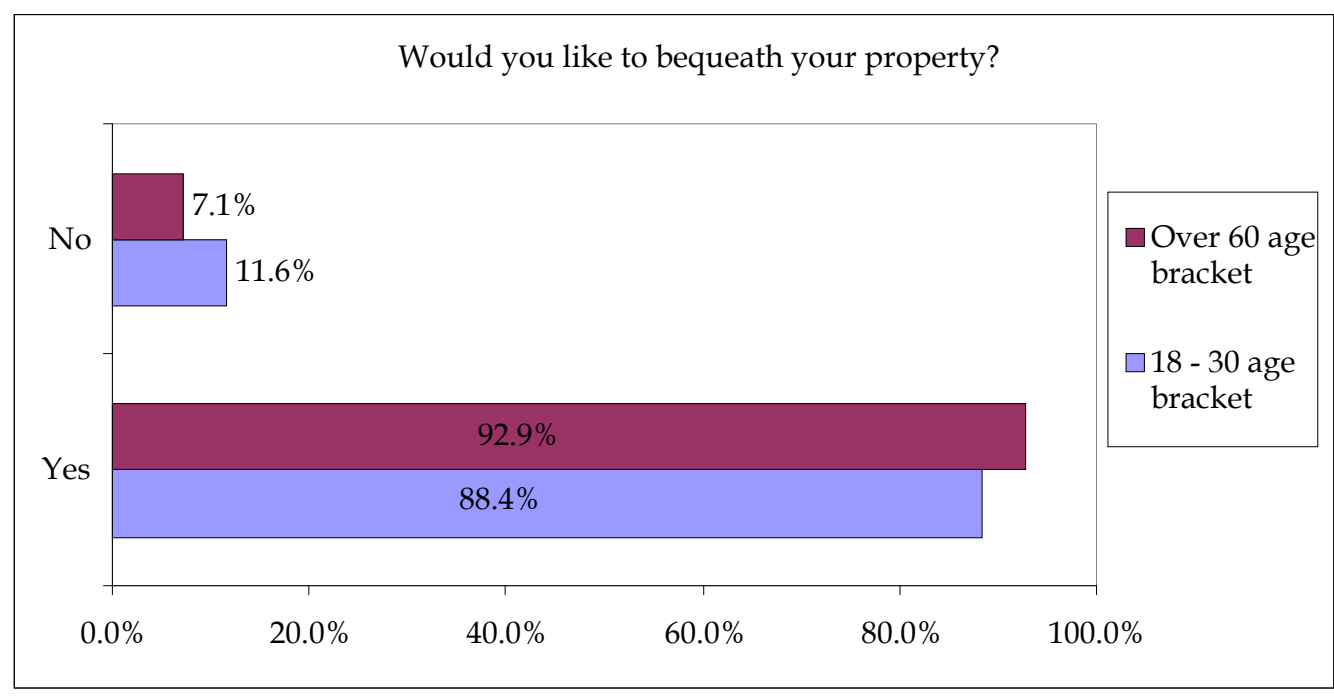

Fig. 8. Attitude towards the possibility of leaving a legacy. Source: own elaboration based on a questionnaire survey.

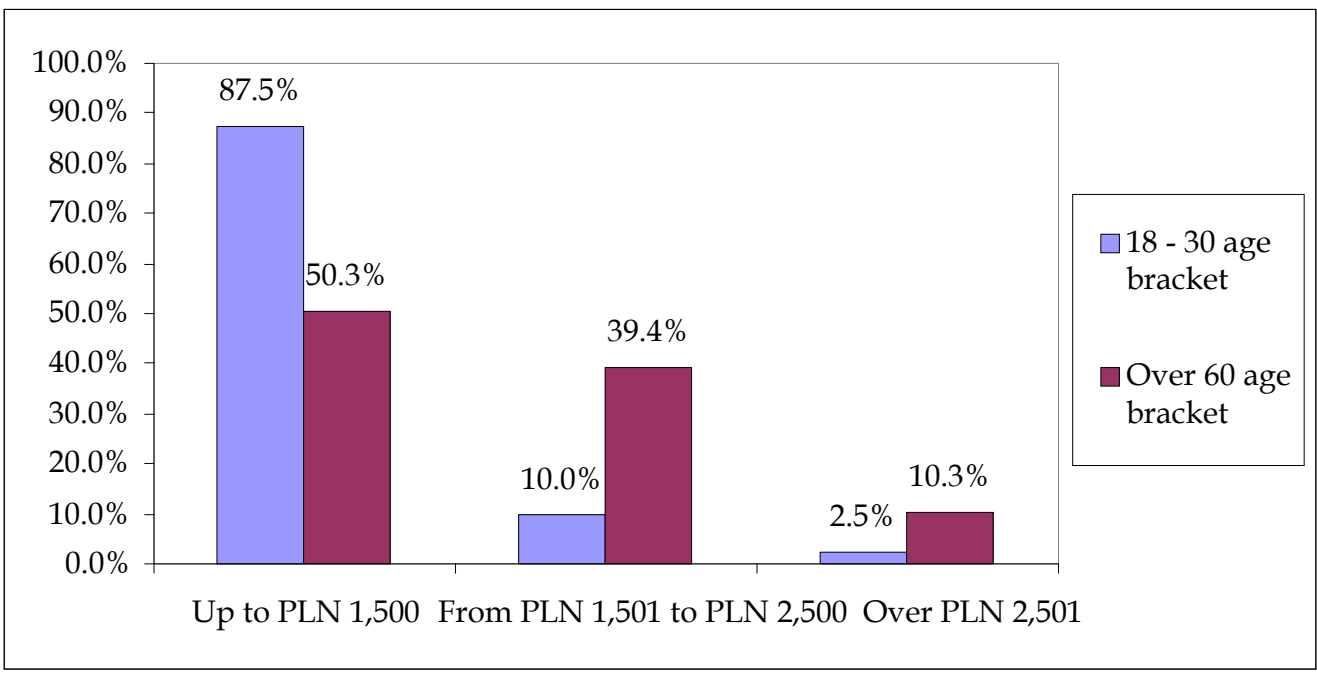

Fig. 9. Average monthly expenditure. Source: own elaboration based on a questionnaire survey.

\section{Summary}

The main goal of the presented article was to determinate the prospects for the development of reverse mortgages from a cultural perspective, by questioning various respondents divided into two groups. Firstly, those aged 18-30 (mostly students from different cities in Poland) and secondly, elderly people over the age of 60 . Despite the negative attitude towards today's retirement benefits as well as rather pessimistic forecasts of recent retirement reforms, the possibility of taking out a reverse mortgage is certainly not a mass phenomenon among representatives of the analyzed study groups. This does not arise from to the lack of information among members of the target group (65\% of senior citizens in the research sample are familiar with the term reverse mortgage). The underlying reason for this seems to be of a cultural origin, which can be characterized as firmly consolidated in land ownership and inheritance. In both age categories, approximately $90 \%$ of the respondents expressed a desire to leave a legacy to family.

The preference for a reverse mortgage agreement seems to be indirectly related to the financial situation of the two age groups and the model of consumption typical of older people. In the presented research, retirees were found to be more common in the higher monthly expenditure range 
and demonstrated a lower tendency to sign an agreement of reverse mortgage. According to the findings of this present study, respondents aged 18-30 are more prone to enter into this form of agreement because of the fact that they earn less than their over 60-year-old counterparts, and do not yet have any descendants. However, the issue of the influence of the financial situation on the number of signed agreements calls for further studies, taking into consideration the marginal propensity to save and consume. The introduction of new legal solutions such as the Reverse Mortgage Bill might reduce the number of people who resign from this course of action because of the non-transparent means of preparing the agreement and the lack of supervision by the Polish Financial Supervision Authority. Nonetheless, it is the cultural factors which play a fundamental role during the decisionmaking process of signing a reverse mortgage agreement in the case of the presented research sample.

\section{Bibliography}

MAJ - WIŚNIOWSKA K., CYCOŃ M., 2011, Formy odwróconego kredytu hipotecznego w Polsce na tle wybranych krajów Unii Europejskiej, Zeszyty Naukowe PTE 11: 195 - 209.

TOUSSAINT J., 2011, Housing wealth in retirement strategies - Towards understanding and new hypotheses Sustainable Urban Areas, Delf University Press.

TOUSSAINT J., ELSINGA M., 2007, Home ownership as a financial resource? Household's perceptions in eight European countries, APNHR Conference, s. 165 - 182.

Ustawa z dnia 23 kwietnia 1964 roku Kodeks Cywilny Dz. U. Nr 16, poz. 93, z późn. zm.

www.cbos.pl, Komunikat badań, BS/77/2012

www.mf.gov.pl, Założenia do projektu ustawy o odwróconym kredycie hipotecznym, 23.09.2011 r. 